\title{
NTRK1 Gene Mutation
}

National Cancer Institute

\section{Source}

National Cancer Institute. NTRK1 Gene Mutation. NCI Thesaurus. Code C153059.

A change in the nucleotide sequence of the NTRK1 gene. 